УДК 378.1:616.1/4

\title{
ШЛЯХИ ОПТИМІЗАЦІї ПРАКТИЧНИХ ЗАНЯТЬ 3 ВНУТРІШНЬОЇ МЕДИЦИНИ ДЛЯ СТУДЕНТІВ 5 ТА 6 КУРСІВ МЕДИЧНОГО ФАКУЛЬТЕТУ В УМОВАХ КРЕДИТНО-МОДУЛЬНОЇ СИСТЕМИ НАВЧАННЯ
}

\author{
Л. П. Мартинюк, Н. В. Грималюк, О. А. Прокопович
}

ДВНЗ “Тернопільський державний медичний університет імені І. Я. Горбачевського МОЗ Украӥни”

\section{WAYS OF OPTIMISATION OF PRACTICAL LESSONS OF INTERNAL MEDICINE FOR 5-TH AND 6-TH YEAR STUDENTS OF MEDICAL FACULTY ACCORDING TO THE CREDIT-TRANSFER SYSTEM OF EDUCATION}

\author{
L. P. Martynyuk, N. V. Hrymalyuk, O. A. Prokopovych \\ SHEI "Ternopil State Medical University by I. Ya. Horbachevsky of MPH of Ukraine"
}

\begin{abstract}
У результаті проведених дискусій щодо вдосконалення навчального процесу в умовах кредитно-модульної системи навчання автори пропонують власний досвід проведення практичних занять 3 внутрішньої медицини та розглядають можливості підвищення якості освосння практичних навичок студентами 5 та 6 курсів.
\end{abstract}

As a result of discussions about improvement of the educational process according to the credit-transfer system the authors offer their own experience of conducting lessons in internal medicine and consider the possibility of improvement of the quality of learning of practical skills by 5-th and 6-th year students.

Вступ. Реформування системи освіти в Україні згідно з принципами Болонської конвенції було зумовлене обранням напрямку євроінтеграції та прагненням вступити до Свропейського Союзу (СС). Проголошення Концепції розвитку ТДМУ ім. І. Я. Горбачевського 27 червня 2006 року окреслило бажання слідувати парадигмам Болонського процесу та приєднатися до співдружності провідних європейських університетів, в межах якої мають діяти єдині вимоги до визнання дипломів про освіту та працевлаштування випускників. Інтеграція української медичної освіти у європейський освітній простір була пов' язана насамперед 3 потребою забезпечення більшої мобільності студентів та викладачів, конкурентоспроможності випускників на світовому ринку праці.

Основна частина. Основні засади, які сповідує кредитно-модульна система (КМС) навчання, полягають у підвищенні якості медичної освіти, відповідності отриманих кваліфікаційних навичок до існуючих потреб, стимулюванні учасників навчального процесу та підвищенні мотивації студентів до самовдосконалення. П'ятирічний досвід впровадження КМС в нашому університеті є прикладом для наслідування для інших вузів України, оскільки система освіти в ТДМУ зазнала гли( Л. П. Мартинюк, Н. В. Грималюк, О. А. Прокопович бокого кардинального реформування, яке постійно триває і вдосконалюється.

Динамічність розвитку сучасного суспільства вимагає застосування нових інноваційних педагогічних методик підготовки кваліфікованих кадрів, а також використання ефективних та перевірених часом (бесіди, лекції, практичні заняття, семінари). При цьому важливим завданням сучасної медичної освіти в Україні є зробити їі максимально наближеною до європейських критеріїв викладання предметів та оцінки знань студентів. Навчання практичних навичок здійснюється з використанням повного арсеналу педагогічних методик, зокрема через досвід, через спостереження та рефлексію, з допомогою абстрактної концептуації, активний експеримент. Для більш успішного засвоєння матеріалу урок побудований так, щоб охопити всі 4 рівні навчання. Кінцева мета освітнього процесу на сьогодні - освоєння студентами спеціальності, формування компетентності у даній галузі, не відкладаючи практичну частину навчання на післядипломний рівень.

Заняття з внутрішньої медицини проводяться на базі університетської лікарні згідно з методикою “Сдиного дня” та тривають 7 академічних годин. В умо- 
вах Болонської системи навчальний процес побудований за цикловим принципом. Внутрішня медицина включає в себе 4 модулі, на 4 та 5 курсі розглядається відповідно модуль 1 та 2 "Основи внутрішньої медицини”, на 6 курсі - модуль 3 “Сучасна практика внутрішньої медицини" та модуль 4 "Невідкладні стани у клініці внутрішньої медицини”. Впровадження Z-системи, яка передбачає поступовий перехід від теорії до практики, має беззаперечні переваги для обох сторін навчального процесу, як для навчальної, так і для навчаючої. Вони полягають у тому, що викладач має змогу найбільш повно висвітлити дану тему впродовж заняття, а студент за достатньої мотивації ії освоїти. Студентам пропонується на початку уроку бліц-контроль вхідного рівня знань у вигляді тестів чи описових завдань 15 хвилин. Після цього практична частина заняття полягає у самостійній роботі студентів біля ліжка хворого під контролем викладача, де вони оволодівають навиками спілкування з пацієнтом, використовувати засади деонтології та комплаєнсу (збирати скарги, анамнез), проводити фізикальне обстеження, призначати комплекс необхідних лабораторних та інструментальних обстежень, трактувати їх результати, проводити диференціальний аналіз, визначати алгоритм лікувальних заходів та принципи первинної та вторинної профілактики. Протягом практичної частини заняття, яка займає 4 години (60\%), студенти беруть участь в обходах професора, самостійно курують тематичних хворих, працюють у бібліотеці, яка оснащена комп’ютерами з можливістю доступу до всесвітньої мережі Internet, необхідними методичними матеріалами та підручниками з різних розділів внутрішньої медицини, проводять самопідготовку до “Кроку 2", користуються електронними матеріалами підготовки до занять на WEB-порталі університету, працюють у тематично-оснащених кімнатах, де також мають можливість WiFi-доступу портативних комп'ютерів. Відмітку про засвоєння практичних навичок за даною темою викладач здійснює у матрикулах. На 5 курсі кожен з студентів отримує хворого, якого курує під наглядом викладача та заповнює навчальну історію хвороби. В кінці кожного розділу внутрішньої медицини проводиться клінічний розбір історії хвороби даного хворого, де студент на основі виділених клінічних синдромів обгрунтовує виставлений діагноз та призначене лікування. Написання і розбір історій хвороб $€$ доброю традицією кафедри і дає змогу викладачеві оцінити розуміння студентом висвітленої проблеми, а студентові скласти повне уявлення про хвору людину, осмислити свої помилки та хибні су- дження, впритул наблизитись до практики, що допомагає визначитись у майбутній спеціальності. Студенти 6 курсу готують мультимедійну презентацію за обраною або запропонованою викладачем тематикою та представляють іï для розбору на семінарському занятті. На нашу думку, дану методику слід розвивати та вдосконалювати шляхом проведення конкурсу на кращу роботу та нагороджувати переможців, делегуючи їх на міжнародний конгрес молодих вчених.

Частина практичної підготовки покладається на позааудиторне опрацювання і передбачає вдосконалення отриманих практичних навиків. Студенти 6 курсу на кожному циклі чергують у профільному відділенні та на практичному занятті наступного дня доповідають про хворих, яких прийняли у стаціонар за час курації.

Семінар триває 2 академічні години та побудований переважно у вигляді дискусії, презентації, колоквіуму чи клінічного розбору, що допомагає студентам систематизувати отримані знання. Викладання кожного циклу внутрішньої медицини проводиться спеціалістами, які мають клінічний досвід у даній галузі і більш наочно на реальних (власних) прикладах розбирають цікаві, складні чи то стандартні випадки, з використанням так званого кейс-методу, коли студенти складають алгоритм дій до змодельованої викладачем ситуації та навчаються клінічного мислення. Оцінювання студентів проводиться за кожну ділянку виконаної роботи (практичну, семінарську та тестовий контроль), після чого виставляється загальна оцінка, яка є складовою загального бала.

Тестовий контроль триває 1 академічну годину, проте студенти, які напередодні ввечері скористалися перевіркою своїх знань у програмі Moodle, мають змогу відпочивати вже $314^{15}$.

На кафедрі функціонує студентський науковий гурток, у якому бажаючі більш глибоко вивчити певний розділ внутрішньої медицини закріплені за конкретним викладачем, який проводить 3 ними науково-освітню роботу. Студентам пропонується написання наукової роботи за певною тематикою, за якою вони проводять огляд літератури, власний розділ дослідження та мають можливість презентувати роботи своєї праці на всеукраїнських конгресах молодих вчених, де вони навчаються та вдосконалюють лекторські здібності.

Самостійна робота студентів підкріплюється забезпеченням необхідних методичних рекомендацій, посібників для позааудиторної роботи з усіх тем, які вивчаються на заняттях, електронних посібників та 
матеріалів підготовки до практичних занять, розміщених на WEB-порталі університету, розроблених викладацьким складом кафедри.

Висновок. Перспективами оптимізації навчально-методичного процесу є подальше впровадження та вдосконалення КМС шляхом підвищення рівня кваліфікації викладачів, проведення практичних занять у сучасних відділеннях задля покращення мож-

\section{Лiтература}

1. Чехія : погляд на систему освіти / Л. С. Фіра, О. І. Острівка, О. Л. Сидоренко, П. Г. Лихацький. - Тернопіль : ТДМУ, 2006. -100 с.

2. Андрейчин С. М. Медична освіта в Словацькій Республіці / С. М. Андрейчин, В. О. Качор.-Тернопіль : ТДМУ, 2006. -248 c

3. Досвід Віденського медичного університету в реформуванні системи освіти. Перспективи співпраці / за ред. Л. Я. Ковальчука. - Тернопіль : ТДМУ, 2006. - 290 с.

4. Деонтологічні аспекти навчання студентів внутрішньої медицини в умовах Болонської системи / В. В. Коломієць, ливості оволодіння студентами сучасних методик обстеження хворих. Доцільним є також ширше залучення студентів випускних курсів до наукової роботи, проведення ними наукового дослідження 3 певної тематики, подальшою презентацією своїх результатів на конкурсній основі й делегацією кращих студентів на конгрес молодих вчених та науковців.

Н. В. Ванханен, Н. В. Грона, В. В. Красьоха-Денисова // Медична освіта. - 2011. - № 3. - С. 95-98.

5. Думанський Ю. В. Освоєння студентами практичних навичок при кредитно-модульній організації навчального процесу : проблеми та пошук шляхів їх вирішення / Ю. В. Думанський, О. М. Талалаєнко, М. Б. Первак // Медична освіта. - 2011. - № 3. - С. 79-81.

6. Колесник Ю. М. Якість підготовки фахівців - головна складова Болонського процесу / Ю. М. Колесник, Ю. М. Нерянов, В. М. Компанієць // Медична освіта. 2011.-№2.-C.71-74. 